Viktorija L.A. Čeginskas*

viktorija.ceginskas@jyu.fi

Department of Music, Art and Culture Studies

P.O. Box 35, FI-40041 University of Jyväskylä, Finland

\title{
The Added European Value of Cultural Heritage. The European Heritage Label**
}

\begin{abstract}
Europe's cultural heritage plays a strategic role in European Union (EU) politics. Heritage is viewed as a shared resource and common good that eventually can produce a broader acceptance of the EU. This article focuses on the exploration of European heritage in the context of the European Heritage Label (EHL), a recent EU heritage action. It first gives an overview of the EHL action and examines the significance attributed to the European dimension of heritage. Next the article discusses the added value of the EHL network of heritage sites for the promotion of European heritage in the context of the European Year of Cultural Heritage (EYCH) 2018. The two initiatives share similar approaches and create opportunities to complement one another. The designation of the EYCH 2018 was an attempt to communicate to a broader European public the understanding that cultural heritage is more than just conservational memory, but also a source of new perspectives
\end{abstract}

\footnotetext{
* Viktorija L.A. Čeginskas currently works as a post-doctoral researcher in the project "Legitimation of European Cultural Heritage and the Dynamics of Identity Politics in the EU" (EUROHERIT, ERC Starting Grant 2015-2020) at the Department of Music, Art and Culture Studies, University of Jyväskylä, Finland. Čeginskas has a Ph.D. in Cultural Heritage Studies from the University of Turku, Finland and a MA in contemporary history, East-European history, and European Ethnology from Christian-Albrechts-University Kiel, Germany. Her research interests include narratives of (multilingual) belonging, identity politics, transnational mobility, and heritage studies in a European context.
}

** The author wishes to acknowledge that the work for this article was supported by the European Research Council (ERC) under the EU's Horizon 2020 Research and Innovation Program (Grant No. 636177) (EUROHERIT). 


\section{GENERAL ARTICLES}

Viktorija L.A. Čeginskas

for the future. The EHL offers new approaches to heritage that challenge national discourses and exclusionary narratives of belonging. The article concludes that the promotion of European heritage serves the political objectives of European integration and may indeed strengthen a sense of belonging to Europe as a cultural and political community.

Keywords: Europe, cultural heritage, European Heritage Label, EYCH 2018, political and cultural community

\section{Introduction}

The European Union (EU) has recognized the important role of heritage in EU legislation and policy-making since the late 1970s, long before the Maastricht Treaty (1993) gave a special legal basis for the EU heritage policy. ${ }^{1}$ While heritage protection is primarily a matter for national, regional, and local authorities, the role of the $\mathrm{EU}$ is to complement national and regional programmes in line with the EU treaties and in accordance with the principle of subsidiarity. The EU is to "protect and enhance the intrinsic and social value of [Europe's cultural] heritage, to strengthen its contribution to economic growth and job creation, and develop its potential for the EU's public diplomacy". ${ }^{2}$ Heritage also plays a central role in the EU policy for managing the legitimation crisis and for evoking a positive public perception among Europeans towards the EU and its institutions. As Tuuli Lähdesmäki ${ }^{3}$ observes, the EU cultural policy is based on ideological goals, in which heritage is used as a political tool for governance for defining and legitimizing the EU. Heritage reflects identity-building capacity based on the process of cultural integration and at the same time fulfils expectations of economic development and sustainability in European regions. ${ }^{4}$ The view of heritage as a strategic resource for forging

\footnotetext{
1 See T. Lähdesmäki et al. (eds.), Dissonant Heritages and Memories in Contemporary Europe, Palgrave Macmillan, forthcoming.

2 European Commission, Communication from the Commission to the European Parliament, the Council, the European Economic and Social Committee and the Committee of the Regions: Towards an Integrated Approach to Cultural Heritage for Europe, 22 July 2014, COM(2014) 477 final, p. 3.

3 T. Lähdesmäki, Rhetoric of Unity and Cultural Diversity in the Making of European Cultural Identity, "International Journal of Cultural Policy" 2012, Vol. 18(1), p. 72.

4 Commission of the European Communities, European File 10/88: The European Community and Culture, May 1988, http://aei.pitt.edu/14726/1/EUR-FILE-10-88.pdf [accessed: 12.02.2019], p. 4. See also Resolution of the Council of 16 November 2007 on a European Agenda for Culture, OJ C 287, 29.11.2007; European Commission, Communication from the Commission to the European Parliament, the Council, the European Economic and Social Committee and the Committee of the Regions. A New European Agenda for Culture, 22 May 2018, COM(2018) 267 final.
} 
cultural identity and social cohesion in the EU is also visible in various EU heritage initiatives, such as the European Heritage Label, the European Heritage Days, or the European Union Prize for Cultural Heritage. ${ }^{5}$

The European Heritage Label (EHL), established in 2011, is a recent EU flagship heritage action that promotes European cultural heritage, with an emphasis on common values and a shared past in Europe. The emphasis on the European dimension of heritage helps to differentiate the EHL as a label with a specific mission, to "bring to life the European narrative and the history behind it" by selecting heritage sites according to their symbolic value for Europe's history and integration. The Label recognizes different cultural monuments, cultural landscapes, memorials, and intangible heritage associated with a place that symbolizes European integration, common European values, and the history and culture of the EU. Hence, the designated sites comprise a broad geographical, temporal, and thematic variety, ranging for instance from prehistoric times (Krapina Neanderthal Site, Croatia) to ancient Greece (Athens) to the collapse of the Soviet Bloc (e.g. Gdańsk Historic Shipyard) and the ratification of the Maastricht Treaty. Since the EHL heritage sites mediate events and processes from different times, it may seem difficult to define what could be a common denominator of the "European" heritage. At the same time however, the EHL action participates in forming a unifying European narrative of what constitutes "European" heritage by granting the Label to specific sites. Such a selective discourse makes it possible to construct the EU in terms of an inevitable, positive trajectory based on extraordinary achievements and similar historical processes or phenomena in Europe's past that strengthen the idea of a "shared European cultural heritage" one that is nevertheless highly heterogeneous and takes into consideration national and regional cultural differences. ${ }^{7}$

There is a growing academic interest in European cultural heritage and recent EU heritage initiatives. Scholars have begun to explore new areas of research related to the European dimension of heritage, and specifically of the EHL sites. This includes a range of interpretations of cultural heritage from a European perspective; the co-existence of different local, regional, national, and European scales; the exploration of new ways to put participatory governance into practice; and ways to share heritage experiences. ${ }^{8}$ New theoretical approaches place the past

5 See E. Niklasson, The Janus-face of European Heritage: Revisiting the Rhetoric of Europe-making in EU Cultural Politics, "Journal of Social Anthropology" 2017, Vol. 2, pp. 138-162; M. Sassatelli, Becoming Europeans. Cultural Identity and Cultural Policies, Palgrave Macmillan, Basingstoke - New York 2009; T. Lähdesmäki, The EU's Explicit and Implicit Heritage Politics, "European Societies" 2014, Vol. 16(3), pp. 401-421.

6 EHL website, https://ec.europa.eu/programmes/creative-europe/actions/heritage-label_en [accessed: 5.12.2018].

7 E. Niklasson, op. cit., p. 155.

8 For instance, see: G. Delanty, The European Heritage. A Critical Re-interpretation, Routledge, London New York 2017; idem, What Unites Europe and What Divides It? Solidarity and the European Heritage Recon- 


\section{GENERAL ARTICLES}

Viktorija L.A. Čeginskas

in a broader context of interpretation and explore its relation to the present and future, which contests traditional views on heritage as a national legacy or inheritance. Rather, they suggest a way to overcome the divide in cultural and political conceptions of heritage by stressing the connectivity of places as a product of historical processes and transnational encounters.

With the designation of a European Year of Cultural Heritage (EYCH), the European Parliament and Council reaffirmed the central role of heritage based on both the principle of shared responsibility and historically rooted social values and political ideals that constitute the basis for the acceptance of the EU as a cultural and political community. ${ }^{9}$ Both the EYCH and the EHL promote Europe's cultural heritage as a shared resource and common good for future generations, one that needs to be safeguarded, conserved, and enhanced. This reflects a new understanding of the purpose and value of a common European cultural heritage as a fundamental source for democratic engagement and a facilitator of unity, belonging, and identity based on, as indicated above, the principles of shared responsibility and historically rooted social values and political ideals.

This article focuses on the exploration of European heritage in the context of the EHL. It draws predominantly on policy documents produced during the preparation, launch, and implementation phases of the EHL initiative ${ }^{10}$ and the official reports published by the European Commission. ${ }^{11}$ First it presents an overview of the EHL action and examines the significance attributed to the European dimension of heritage. Next it explores new approaches to European heritage offered by the EHL; approaches which challenge national discourses of heritage by combining various local, regional, and national perspectives and promoting a transnational interpretation of cultural heritage based on shared values and principles. Next the article discusses the added value of the EHL network for the promotion

sidered, "Asian Journal of German and European Studies" 2018, Vol. 3(3), pp. 1-9; S. Kaiser, The European Heritage Label. A Critical Review of a New EU Policy [Ph.D. diss.], University of Illinois 2014; M. Sassatelli, op. cit.; T. Lähdesmäki, The EU's Explicit and Implicit Heritage Politics; eadem, Politics of Tangibility, Intangibility, and Place in the Making of European Cultural Heritage in EU Heritage Policy, "International Journal of Heritage Studies" 2016, Vol. 22(10), pp. 766-780; T. Lähdesmäki, K. Mäkinen, Dynamics of Scale in the Making of a European Cultural Heritage in EU Heritage Policy, in: T. Lähdesmäki, S. Thomas, Y. Zhu (eds.), Politics of Scale. New Direction in Critical Heritage Studies, Berghahn Books, New York 2019.

9 Decision (EU) 2017/864 of the European Parliament and of the Council of 17 May 2017 on a European Year of Cultural Heritage (2018), OJ L 131, 20.05.2017, p. 1.

10 European Commission, European Heritage Label. Guide for Candidate Sites, Brussels 2011; Decision No. 1194/2011/EU of the European Parliament and of the Council of 16 November 2011 establishing a European Union action for the European Heritage Label, OJ L 303, 22.11.2011, p. 1.

11 European Commission, European Heritage Label. 2013 Panel Report, Brussels 2013; European Commission, European Heritage Label. 2014 Panel Report, Brussels 2014; European Commission, European Heritage Label. 2015 Panel Report, Brussels 2015; European Commission, European Heritage Label. Panel Report on Monitoring, 19 December 2016; European Commission, European Heritage Label. 2017 Panel Report, 5 December 2017. 
of European heritage to a broader public in the context of the EYCH 2018. Despite approaches which offer fruitful outcomes and the possibility of the two initiatives to complement one another, the anticipated cooperation has failed. The article concludes that the EHL nevertheless possesses the capacity to initiate a public debate that may promote a broader appreciation of European heritage and support social cohesion in Europe.

\section{Implementation of the EHL}

The European Heritage Label was launched as an intergovernmental initiative at the instigation of Spain and France in 2006 and as a direct reaction to the rejected referenda on the Treaty establishing a Constitution for Europe (2004) ${ }^{12}$ in France and the Netherlands. However, as this form was considered not efficient enough, the EHL was subsequently developed into an EU heritage action by the decision of the European Parliament and Council in 2011. ${ }^{13}$ The official transformation was based on Article 167 of the Treaty on the Functioning of the European Union (TFEU), which gives a formal legal competence to European bodies to safeguard, develop, and disseminate culture in Europe. ${ }^{14}$ The decision of the European Parliament and Council provided financial funding of $€ 650,000$ for the implementation of the action during the period of 1 January 2012 to 31 December 2013. ${ }^{15}$ After four selection rounds - in 2013, 2014, 2015, and 2017 - the Label currently counts 24 participating EU Member States, and 38 designated heritage sites in 18 countries (see Table 1). A recent roadmap envisions more than 100 heritage sites across the EU and in neighbouring countries by $2030,{ }^{16}$ which reflects the increasing interest in the EHL among heritage sites at the national level and by the participating Member States.

The change from an intergovernmental initiative into a formal EU action was a response to the call by various Member States for a more transparent selection process, guided by established and concrete criteria that applied to all Member States. ${ }^{17}$ The decision was also taken with the aim to enhance the Label's credibility, visibility, and prestige in and outside of Europe, associated with concrete expectations to stimulate cultural tourism and intercultural dialogue and support economic and sustainable development in EU Member States. ${ }^{18} \mathrm{New}$ criteria and selection

\footnotetext{
12 Signed on 29 October 2004 (not in force), OJ C 310, 16.12.2004.

13 Decision No. 1194/2011/EU.

14 Treaty on the Functioning of the European Union (consolidated version), OJ C 326, 26.10.2012, p. 47.

15 Decision No. 1194/2011/EU, art. 20.

16 European Commission, European Heritage Label. 2017 Panel Report, p. 8.

17 S. Kaiser, op. cit., p. 31.

18 European Commission, A Renewed EU Tourism Policy: Towards a Stronger Partnership for European Tourism,
} 17 March 2006, COM(2006) 134 final; European Commission, Commission Staff Working Document. Sum- 


\section{GENERAL ARTICLES}

Viktorija L.A. Čeginskas

procedures were introduced during the process of becoming a heritage action, and previously awarded sites were therefore asked to re-apply to the action.

During the preparation phase of the Label, "lively" debates about the EHL took place in the European Parliament. Members of the European Parliament from the European Freedom Group (now Europe of Freedom and Democracy [EFD] Group), dominated by anti-European national and right-wing parties, such as the UKIP and Lega Nord, argued for rejection of the proposal for the action, arguing that European sites would be in conflict with regional and national identities. ${ }^{19}$ However, a majority in the European Parliament approved the legislative resolution and official transformation of the Label at their voting sessions in 2010. ${ }^{20}$

The EHL is open to the voluntary participation of all EU Member States, including those Member States which did not previously participate in the intergovernmental initiative (e.g. Finland, Ireland, Luxembourg, Sweden, and the UK). ${ }^{21}$ While the prospect of a "Europeanization" of cultural heritage may account for the hesitation of the UK, which sees a conflict of interests between the national and supranational levels, this is not necessarily the case for the other countries. The abstention of Sweden can be interpreted in terms of a prioritization of either or both the international and Nordic geopolitical context. Sweden became a member of the EU in 1995 and has rejected participation in the Euro zone. As a result of the recent financial crises, the level of confidence in Europe has diminished in Sweden, similarly as in many other European countries. However, a recent document of the Swedish National Heritage Board reveals that Sweden's absence from the Label is more likely the result of a strategic assessment of the costs and effects of the EHL for Swedish heritage sites, based on a careful analysis of Denmark's experience as regards the EHL application procedure in 2013. ${ }^{22}$ All three Danish proposals were rejected on grounds of not fulfilling the Label's criteria.

mary of the Impact Assessment. Accompanying Document to the Proposal for a Decision of the European Parliament and of the Council Establishing a European Union Action for the European Heritage Label, 9 March 2010, $\operatorname{COM}(2010) 76$ final, p. 4.

19 A. Rendall, Euro MPs Back Creation of 'European Heritage Label', BBC, 16 November 2011, https://www. bbc.com/news/uk-politics-15755426 [accessed: 10.02.2019]. See also S. Kaiser, op. cit., pp. 35-37.

20 European Parliament legislative resolution of 16 November 2011 on the Council position at first reading with a view to the adoption of a decision of the European Parliament and of the Council establishing a European Union action for the European Heritage Label, 16 November 2011, P7_TA(2011) 0502. It should be noted that the proposal against the label tabled by the EFD Group was rejected by 517 votes to 59 , with 63 abstentions. For detailed votes of the second reading on the EHL on 16 November 2011, see also the website: parltrack.euwiki.org/dossier/2010/0044(COD).

21 European Commission, European Heritage Label. Guide...

22 Riksantikvarieämbetet, Rapport från Riksantikvarieämbetet: Europeiskt kulturarvsmärke, Riksantikvarieämbetet, Stockholm 2016. Document shared by the Finnish National Heritage Agency, the Finnish National Board of Antiquities. 
The Swedish document supports participation in the EHL and recognizes the added value of a European cultural heritage in serving the common interests among European States in a time of increasing nationalism. However, Swedish National Heritage Board concluded it would be unlikely that the nation's heritage sites would meet the Label's criteria, and therefore recommended against participation. The Board did not rule out future participation. The reasons as stated by the Board are based on Sweden's neutrality in both the First and Second World Wars, and Sweden did not directly contribute to the development of the European Economic Community in the 1950s. This reveals a rather narrow reading and understanding of Europe's cultural heritage and complex historical entanglements, as well as sheer neglect of Sweden's role during the Second World War. In Finland, the Minister of Education, Culture and Sport, Sampo Terho, officially announced Finland's participation in the EHL on 28 November 2018, giving up the country's hitherto wait-and-see attitude, which was in large part based on Sweden's official assessment. The Finnish National Heritage Agency plans to host preparatory workshops for core stakeholders in 2019 in order to assess interest among heritage sites and discuss possible strategies for implementing the Label.

By definition, the EHL covers a diverse selection of heritage sites and "embraces all types of cultural heritage from all periods". ${ }^{23}$ This selection includes a variety of historical, archaeological, urban, natural, and cultural heritage sites, as well as intangible heritage and cultural objects associated with a place or books or archives, which are eligible to apply provided they can prove their contribution to the progress of European history, integration, and unity. ${ }^{24}$ The EHL also encourages the joint application of a number of transnational and national thematic sites, which are eligible for the Label if they comply with the criteria and demonstrate the European added value of their joint application and a clear thematic link. In its implementing decision of 2 March 2012, the Commission stressed that the Label will only designate sites which have played a key role in the history of Europe and which offer activities that will facilitate peer learning. ${ }^{25}$ The Label is awarded to successful applicants based on the following three categories of criteria:

(1) the symbolic European value of the site;

(2) the quality of the project proposed to promote and communicate its European dimension to European audiences;

(3) the quality of the work plan showing that the candidate site has adequate operational capacity to implement the submitted project and thereby meet the criteria required for the label. ${ }^{26}$

23 European Commission, European Heritage Label. Panel Report... 2016, p. 6.

24 Decision No. 1194/2011/EU, art. 2.

25 European Commission, Commission Implementing Decision of 2.3.2012 on the Adoption of the 2012 Work Programme of a European Union Action for the European Heritage Label, 2 March 2012, C(2012) 1317 final, p. 4.

26 European Commission, European Heritage Label. Guide..., p. 6. 


\section{GENERAL ARTICLES}

Viktorija L.A. Čeginskas

The first category concerns the permanent features of a site. The heritage sites need to demonstrate one or several of the following criteria: their pan-European nature extending beyond the national borders of a Member State; their links with key European events, personalities, or movements; or their role in the development and promotion of common values that underpin European integration. ${ }^{27}$ The EHL seeks to safeguard and strengthen the process of European integration with an emphasis on shared values, history, and culture founded on the principles of freedom, democracy, respect for human rights, the appreciation of national, regional, cultural, and linguistic diversity, tolerance, and solidarity. It further attempts to increase the importance of heritage in the economic and sustainable development of regions and foster democratic values and human rights, including promotion of a site as a catalyst for contemporary creativity. ${ }^{28}$

The second and third categories refer to a specific project and management plan which the candidate sites must submit together with their application in order to ensure their operational capacity to carry out the activities related to the site's management, protection, quality, public access, promotional capacity, and communication of its European significance..$^{29}$ The application procedure for the EHL and the subsequent monitoring of the participating EHL sites pay specific attention to the heritage sites' operational capacity and to projects aimed at facilitating and strengthening communication of the European dimension to European audiences, thus increasing the Label's visibility at large. Likewise, the operational capacity of EHL heritage sites is connected with concrete strategic expectations of raising the profile and attractiveness of European heritage sites as tourist destinations in the context of global competition and sustainability, and anticipates the Label's status in terms of a high-quality label that makes it possible to compete on equal terms with other well-known cultural initiatives. ${ }^{30}$

The selection of candidate sites takes place in two stages. While the Member States participating in the EHL are responsible for the pre-selection and monitoring of the sites in their respective territories, a panel of independent European experts (the European Panel) makes the final decision and limits the selection to one site per year per Member State. ${ }^{31}$ The European Panel tries to avoid double awards if possible, thus sites and initiatives already included in the Council of Europe initiative (Cultural Routes) are unlikely to receive the EHL. ${ }^{32}$ Similarly, the monitoring

\footnotetext{
27 Decision No. 1194/2011/EU, art. 7.

28 Ibidem.

29 European Commission, European Heritage Label. Guide..., p. 8; European Commission, European Heritage Label. Panel Report... 2016, pp. 8-10.

30 See Decision No. 1194/2011/EU.

31 European Commission, European Heritage Label. Guide..., p. 9.

32 Ibidem.
} 
of the sites takes place in a two-step process at the national and European level to ensure that each EHL heritage site continues to meet the criteria and respect the project and work plan submitted in its application. First, the National Coordinators collect information from the sites, prepare a report, and send it to the European Commission. Based on these reports, the European Panel then issues its report, together with recommendations to be taken into account. ${ }^{33}$ Based on the monitoring results - in terms of meeting of the criteria and respecting the submitted project and working plans - there exists the possibility of withdrawal or renunciation of the Label. ${ }^{34}$ According to the decision implementing the EHL action, the Commission makes all reports, recommendations, and notifications of the European Panel public. ${ }^{35}$

\section{New Approach to Heritage: An Explicit European Dimension}

The EHL differs from other heritage initiatives, such as the UNESCO World Heritage List, the Cultural Routes of the Council of Europe, or the European Union Prize for Cultural Heritage/Europa Nostra Award, by putting a particular emphasis on the symbolic European dimension of the designated heritage sites. The focus of the Label is not on the preservation of the sites or their aesthetic or architectural quality, as is the case in other cultural initiatives, but on the promotion of Europe's common past and values.

UNESCO enlarged the concept of heritage from a local and national level to an international level by embracing the understanding of heritage as a collocation of values and objects and the sites they embody. Hence, heritage is not just "something old" but also can be generated in the present in terms of intangible performances and qualities. ${ }^{36}$ While the UNESCO World Heritage List was the first supranational compilation of sites of cultural value, the European dimension inherent in the EHL also supersedes local, regional, and national heritage and thereby follows the UNESCO interpretation of intangible cultural heritage. However, UNESCO uses values to protect the past as well as national and cultural diversity, with an emphasis on the conservation of sites and intangible cultural practices, whereas only sites with rigorous management and excellent maintenance are awarded the European Heritage Label. The EHL demonstrates a shift in the understanding of heritage from mere conservation and protection to an increasingly

\footnotetext{
33 European Commission, European Heritage Label. Panel Report... 2016.

34 Decision No. 1194/2011/EU.

35 Ibidem. See also European Commission, European Heritage Label. 2013...; European Commission, European Heritage Label. 2014...; European Commission, European Heritage Label. 2015...; European Commission, European Heritage Label. Panel Report... 2016; European Commission, European Heritage Label. 2017...
}

36 Convention Concerning the Protection of the World Cultural and Natural Heritage, 16 November 1972, 1037 UNTS 151, art. 1, 6; Convention for the Safeguarding of the Intangible Cultural Heritage, 17 October 2003, 2368 UNTS 1. 


\section{GENERAL ARTICLES}

Viktorija L.A. Čeginskas

political instrument that serves identity-building purposes and the expectations of economic benefit and sustainable development in the EU. ${ }^{37}$ However, the request for an EHL designation is generated not by the EU, but by regional and national actors, ${ }^{38}$ thus presenting a decentralized approach. Hence it may be argued that the EHL award shows what local, regional, and national actors consider as European heritage, and not what EU institutions might identify as such. This approach corresponds to the EU cultural policy of recent decades, which proposes treating "Europe" as a brand product and promoting both a sense of shared unity and commonality as well as the benefits of membership in the EU as "products" that should be mediated to the European public. ${ }^{39}$

Fieldwork carried out within the framework of a broader academic research project studying the $\mathrm{EHL}^{40}$ reveals that local and European levels try to promote and mediate "European" values in terms of universal social and moral values and mindsets that are closely linked with historical processes in the European context, and therefore considered of importance for understanding Europe's entangled past. Similar to the Council of Europe Framework Convention on the Value of Cultural Heritage for Society (known as the Faro Convention), ${ }^{41}$ which introduces a new understanding of the purpose of cultural heritage for both the present and future relationships in civic society, the EHL highlights the social dimension of Europe's common heritage. The EHL thus offers new approaches of understanding cultural heritage connected with the facilitation of unity, belonging, and democratic participation and engagement rooted in social values and political ideals.

First, the EHL promotes a transnational interpretation of cultural heritage, substantiated by the emphasis on shared values and principles and the appreciation of national and regional cultural diversity, all of which challenge the typically dominant national discourse of heritage. The Label attempts to illustrate a broader approach to the meaning of a European heritage by showing the impact of transnational networking and exchange of ideas on diverse philosophical, cultural, social, and political developments at different times and places in Europe. ${ }^{42}$

37 Decision No. 1194/2011/EU, pp. 1-9.

38 European Commission, European Heritage Label. Guide...

39 See S. Kaiser, op. cit., p. 13. See also W. De Clercq, Reflections on Information and Communication Policy of the European Community. Report by the Group of Experts Chaired by Mr. Willy De Clerca, Member of the European Parliament, March 1993, http://aei.pitt.edu/29870/1/DE_CLERCQ_REPORT_INFO._COMM._POLICY. pdf [accessed: 12.02.2019].

40 Within the framework of the project "Legitimation of European cultural heritage and the dynamics of identity politics in the EU" (EUROHERIT), an independent academic research project at the University of Jyväskylä, fieldwork was conducted at $11 \mathrm{EHL}$ sites in ten countries between August 2017 and February 2018. For more information, see: http://www.jyu.fi/euroherit.

4127 October 2005, CETS 199.

42 See T. Lähdesmäki, K. Mäkinen, op. cit. 
By implying that the EHL sites belong to a "very special club", the European Panel highlights the extraordinary aspect of the EHL discourse on Europe's shared heritage and history and seeks to mediate to European citizens that "there is something 'European' about us and about our heritage". ${ }^{43}$ Hence fostering of the European dimension of cultural heritage is assumed to possess the capacity to trigger an emotional experience and ideally produce a sense of belonging and solidarity among European citizens. ${ }^{44}$

Second, the EHL has a clear educational objective, namely providing high-quality information to the widest possible public that can help Europeans to "learn about our shared cultural heritage, the history of Europe, the building of the EU, and the democratic values and human rights underpinning the process of European integration". ${ }^{45}$ The designated heritage sites are requested to design didactic activities aimed specifically at young European citizens in order to support the process of European cultural and political integration by increasing appreciation of European values and of the benefits of belonging to the $\mathrm{EU}$ and strengthening a sense of identity and belonging to Europe. ${ }^{46}$ The activities at the EHL sites also aim to facilitate intercultural dialogue and underpin the understanding of Europe's past in terms of a shared, yet diverse, cultural heritage by drawing attention to the interconnectivity of histories and cultures. ${ }^{47}$

Third, the EHL can be distinguished from other initiatives by its emphasis on the heritage sites forming part of a network, through which the sites can support each other to promote their European significance. ${ }^{48}$ The EHL network of heritage sites participates in the narration of the origin of the EU. The narratives of founding myths serve to emphasize the historical continuity in the transmission of a common cultural legacy on the one hand, and on the other communicate a temporal break that resulted in the development of a European civic and political community after the Second World War. ${ }^{49}$ However, as the designation of the Label includes both tangible cultural and natural heritage sites as well as social and cultural practices associated with a specific place, the network of different heritage sites helps to convey the understanding that a European dimension of heritage is not static or frozen in a specific historical event or cultural practice. Instead, the EHL net-

\footnotetext{
43 European Commission, European Heritage Label. Panel Report... 2016, p. 40.

44 See T. Lähdesmäki, Politics of Affect in the EU Heritage Policy Discourse: An Analysis of Promotional Videos of Sites Awarded with the European Heritage Label, "International Journal of Heritage Studies" 2017, Vol. 23(1), pp. 709-722.

45 European Commission, European Heritage Label. Guide..., p. 4.

46 See Decision No. 1194/2011/EU; European Commission, European Heritage Label. 2017...

47 T. Lähdesmäki, The EU's Explicit and Implicit Heritage Politics, pp. 407-409.

48 European Commission, European Heritage Label. 2017...

49 T. Lähdesmäki, Founding Myths of European Union: Europe and the Workings of Power in the European Union Heritage and History Initiatives, "European Journal of Cultural Studies" 2018, pp. 1-18.
} 


\section{GENERAL ARTICLES}

Viktorija L.A. Čeginskas

work offers shared heritage experiences at a European level, which facilitate the understanding of the European dimension of heritage in terms of a process, one interrelated with different local, regional, and national perspectives, which in turn helps to emphasize the transnational aspect of European heritage.

The EHL needs public visibility in order to attain its objectives and raise European citizens' appreciation of shared European values and benefits, in particular among young Europeans. ${ }^{50}$ The Label operates on the assumption that the conservation, public awareness, and transmission of cultural heritage to future generations depends on the ability to reach a wide array and large number of citizens and get them to perceive, understand, and appreciate European cultural heritage as a value and quality, as formulated in the decision implementing the action..$^{51}$ The success of the EU's integration policy strongly depends on the efficiency of the European Commission in communicating to diverse European audiences what a shared "European" heritage means and how it can positively affect European integration and produce a sense of cohesion and solidarity across national borders. The European dimension of heritage, as promoted by the EHL, is not viewed as fixed or singular but instead the narratives are based on notions of cultural plurality and shaped by manifold historical processes and transnational developments that recognize interconnected memories and networks that extend even beyond Europe.

The European Commission pursues a particular objective with the promotion of European cultural heritage as a shared and common experience, based on the idea that its broader public recognition adds value to the EU integration processes. However, heritage is an equally important category in the nationalistic and anti-European discourses of populist movements, which contribute to the polarization in European societies by exploiting the idea of European heritage for their own goals and evoking partiality and prejudice against certain groups. ${ }^{52}$ Whether the concept of a European heritage emphasizes a greater networked space between different cultures and societies (i.e. through migration) or the processes affecting social relations in terms of creating a global space, contemporary European societies are nevertheless shaped by conflicting conceptions of political community rather than by one founding tradition. ${ }^{53}$ Thus current approaches to heritage studies view

50 See Decision No. 1194/2011/EU, art. 5; European Commission, European Heritage Label. 2017..., pp. 7-8.

51 Decision No. 1194/2011/EU.

52 G. Delanty, The European Heritage...; C. De Cesari, European Heritage and Cultural Racism, paper presented at the conference "The Cultural Heritage of Europe @2018. Re-assessing a Concept and Re-defining Its Challenge", Institut national d'histoire de l'art (INHA), Paris, 4-5 June 2018; E. Niklasson, H. Hølleland, The Scandinavian Far-right and the New Politicization of Heritage, "Journal of Social Anthropology" 2018, Vol. 18(2), pp. 121-148.

53 G. Delanty, Entangled Memories: How to Study Europe's Cultural Heritage, "The European Legacy" 2017, Vol. 22(2), p. 135. 
the past in a broader context than just a form of legacy, and highlight its relevance as a form of social and cultural action that facilitates social cohesion, a shared identity, and public engagement both for the present and future. ${ }^{54}$ The past can be constructed through various processes that have the capacity to generate solidarity. The discursive meaning-making process of European cultural heritage connects to the twin questions of what heritage implies for shaping a sense of belonging in contemporary European societies, and who participates in this process. While civic solidarity does not overcome differences, it makes plural interpretations of the past possible, as solidarity can be employed both in an inclusive and exclusive perception of community, which has the potential to maintain and challenge the political status quo at the same time.

\section{Complementary Approaches between the EHL and EYCH 2018}

The series of initiatives and events which took place across Europe during the European Year of Cultural Heritage 2018 encouraged people to explore diverse forms of cultural heritage, both tangible and intangible; and natural and digital heritage. The motto of the year - "Our heritage: where the past meets the future" - supported the understanding that cultural heritage is more than just conservational memory, but also a source of new perspectives for the future. The designation of a European Year served to strengthen a sense of unity in Europe, which complies with the political and cultural agenda of creating a "People's Europe". ${ }^{55}$ It equally promoted acceptance of European integration based on the idea that the present-day EU can be traced back to Europe's past, and that a shared cultural community constitutes the basis for the ensuing political community in current times.

The EHL action and the EYCH 2018 share similar approaches and offer the opportunity to complement one another in their emphasis on developing transnational dialogue, intercultural exchanges, and broader participation. The EYCH 2018 aimed to encourage an appreciation of Europe's cultural heritage as a shared resource and to reinforce a sense of belonging to a common European space by engaging and addressing young people in particular. Its series of activities and events also included educational activities and programmes for raising greater public awareness of Europe's common history and values. ${ }^{56}$ Furthermore, the EYCH 2018 encouraged exchanges among actors from various national, regional, and local public administrations and private and civic organizations, which aided in sharing

54 Ibidem; see also R. Harrison, Heritage. Critical Approaches, Routledge, New York 2013.

55 C. Shore, Building Europe. The Cultural Politics of European Integration, Routledge, London - New York 2000.

56 European Commission, European Heritage Label. 2017...; Decision (EU) 2017/864, op. cit. 


\section{GENERAL ARTICLES}

Viktorija L.A. Čeginskas

experiences and best practices and constituted a resource to which the EHL network on its own had no access.

The EYCH was present in social networks and the media and was able to offer a larger platform for promoting a European and transnational dimension of cultural heritage to a broad and diverse European public. In turn, the EHL network of heritage sites provides an explicit European dimension of heritage that can facilitate insights into the ways in which historical transformations and contemporary processes interrelate, and how European heritage supports meaningful connections and a sense of shared history in society based on complex entanglements. ${ }^{57} \mathrm{How}-$ ever, the EYCH 2018 was, to date, a one-time-event, which aimed to "celebrate" European heritage across Europe. Despite the various campaigns, events, and activities it did not necessarily manage to convey a coherent understanding of European cultural heritage, which was one of the aims of the European Commission. In contrast, the EHL is a long-term action and the focus on presenting European heritage through the network of heritage sites has the ability to produce a better understanding of what constitutes the "European" dimension of heritage, which may result in strengthening social cohesion and a sense of belonging among European citizens and residents.

The EU's cultural and integration policies depend on the tangible presentation of European heritage not as something abstract or theoretical, but in terms of something concrete with which people can identify in a durable way. However, scholars point out that the EU tends to emphasize a story of the extraordinary or a saga of Europeanism ${ }^{58}$ that transmits specific ideological positions, moral codes, as well as social and societal values, such as peace, democracy, justice, the rule of law and human rights, tolerance, and solidarity. At the same time, the emphasis on the European symbolic value of heritage gives the designated EHL sites freedom in their interpretation and actual representation of "European" heritage and history to the broader public. ${ }^{59}$

The EHL network adds value to European heritage and assumes a two-fold responsibility. The heritage sites account for both producing and realizing examples of "European" heritage and communicating the complexity of the meaning the European dimension of heritage implies for European societies. The EHL sites do not focus only on the extraordinary, but also include banal routines and practices that help in situating the visitors in their contemporary socio-political world, and establish connection between people, places, and practices across geographical, politi$\mathrm{cal}$, and temporal boundaries. Heritage sites have the capacity to create affective

57 G. Delanty, Entangled Memories...; R. Harrison, op. cit., p. 39.

58 See H.-J. Trenz, The Saga of Europeanisation. On the Narrative Construction of a European Society (Arena Working Paper 7/2014), July 2014, https://www.sv.uio.no/arena/english/research/publications/arena-working-papers/2014/wp7-14.pdf [accessed: 5.11.2018]; see also T. Lähdesmäki, Founding Myths...

59 See T. Lähdesmäki, The EU's Explicit and Implicit Heritage Politics, p. 412. 
connections and encounters between cultural ideas and people, which emphasize commonalities between different groups based on shared cultural meanings and heritage. ${ }^{60}$ The EHL heritage sites also assist in the deconstruction of national narratives and offer a critical exploration of the complex networks of power and entanglements by highlighting the dynamic and social processes related to Europe's past, and calling attention to the political (ab)use of heritage to affect people's experiences of social, economic, and political structures and relationships. ${ }^{61}$

The network of EHL heritage sites consequently helps to highlight the social dimension of heritage and the importance of human agency, which can assist in strengthening the understanding of European heritage as an inclusive and continuously evolving process based on the making, reproduction, interpretation, and addition of heritage by different groups of people and individuals. Thus, the sites offer illustrative and tangible examples that can increase public awareness of the extent of historical entanglements and mutual enrichment in Europe's past. ${ }^{62}$ The Label's public representation and visibility enables people to better understand the historical reasons for cultural belonging and heritage and helps them develop their multifaceted cultural, local, regional, national, and European identities, which also relate to topical issues such as migration. Hence, the EHL network and EYCH 2018 together offered an opportunity for initiating a debate among a broader European public on what constitutes Europe's shared heritage and who belongs to Europe in terms of a specific cultural and political community by encouraging reflections on European history and its legacy in the contemporary world. ${ }^{63}$ Such a debate based on heritage experiences highlights to a broader public the interplay between various developments, approaches, and partnerships through which places, objects, and values "become" heritage and acquire shared meanings in an interactive process within a specific social context. ${ }^{64}$

Paradoxically, while the EYCH 2018 website lists a number of high-profile partners from cultural initiatives, organizations, and stakeholders that cooperated closely with the EU to promote the year, such as UNESCO, Network of European Museum Organizations, Europa Nostra, ICOM Europe, or the European Cultural Tourism Network, it omits any explicit mention of the EHL and the network of heritage sites. ${ }^{65}$ While the EHL sites participated either alone or in cooperation with other EHL sites in the European Year, the European institutions missed the oppor-

60 P. Schorch, E. Waterton, S. Watson, Museum Canopies and Affective Cosmopolitanism. Cultivating Cross-cultural Landscapes for Ethical Embodied Responses, in: D.P. Tolia-Kelly, E. Waterton, S. Watson (eds.), Heritage, Affect and Emotion. Politics, Practices and Infrastructures, Routledge, London - New York 2017, p. 98.

61 R. Harrison, op. cit., p. 113. See also G. Delanty, The European Heritage...

62 See G. Delanty, The European Heritage...

63 Ibidem.

64 T. Lähdesmäki, The EU's Explicit and Implicit Heritage Politics, p. 405.

65 EYCH website, https://europa.eu/cultural-heritage/about_en. 


\section{GENERAL ARTICLES}

Viktorija L.A. Čeginskas

tunity to create a visible and complementary synergy between the two initiatives. The absence of the EHL seems particularly odd in light of the fact that the European Commission refers to both the EHL and $\mathrm{EYCH}$ in the context of promoting European cultural heritage as a basis for producing positive associations with the EU as a cultural community and for fostering a sense of belonging and identification with the $\mathrm{EU}$ as a political community. ${ }^{66}$

At this stage, it is only possible to speculate about the reasons for the failed cooperation at the national and European levels. Future evaluations may provide concrete answers. However, the analysis of fieldwork data of the EHL action shows an insufficient cooperation between the EHL national coordinators, who do not manage to develop synergies between the different national offices in the Member States. It is therefore likely that a confusion of task division and a resulting miscommunication between the two actions, in particular between the respective national coordinators' offices of the EYCH and EHL actions in the participating Member States, may account for the lack of cooperation. Both actions would have benefitted from a joint and supervisory office created at EU level to coordinate support and develop synergy between them. However, despite the fact that the Maastricht Treaty gives the EU legal competence for conducting cultural policy, cultural heritage (including the maintenance, restoration, accessibility, and exploitation of cultural heritage) is still viewed as an inherent part of the competence and national realm of EU Member States. The EU cultural policy is characterized by multilevel governance between different actors at different levels. ${ }^{67}$ The current practices, as well as the competing and uncoordinated structures among the EU Member States, make it difficult to develop synergies and collaboration between the different Member States.

Furthermore, the missed opportunities to use both the EYCH as a platform and the strong European dimension inherent in the EHL network suggest serious difficulties in the EU's communication and promotion strategies for contextualizing "European" cultural heritage and mediating it to a broader audience at the national and European levels. This reveals a gap between the political intentions for developing a new understanding of European heritage in terms of a larger framework that incorporates and connects manifold competing interpretations of memories, narratives, and perspectives ${ }^{68}$ and their practical implementations aimed at increasing social cohesion across European societies. The increasing academic interest in the Label and other EU cultural initiatives may contribute to produce more transparency and help to improve the coordination of diverse EU initiatives aimed at explaining what European heritage is and promoting it to a broader public.

66 See T. Lähdesmäki, The EU's Explicit and Implicit Heritage Politics, p. 407.

67 See also COM(2014) 477 final, pp. 2-4.

68 G. Delanty, Entangled Memories... 


\section{Conclusions}

Many European societies currently face increasing social, political, and economic insecurities and the crisis of political legitimation and representation affects both the EU and many European societies. The emphasis on a shared European heritage and interconnected past can be a topical and useful way to overcome differences and mitigating the fragmentation in European societies we are currently witnessing. The European dimension of heritage refers to the idea of transnational entanglement and the interconnectivity of plural cultures and heritages in Europe's past, which may also include non-European perspectives and result in a commitment to a shared world rather than in an original culture of its own. ${ }^{69}$

With the designation of a European Year of Cultural Heritage, the European Commission pursued the objective of raising the appreciation of Europe's cultural heritage as part of the collective memory and identity of European citizens. The aim of the EYCH was to encourage more people to discover and engage with Europe's cultural heritage all across Europe, and to reinforce a sense of belonging to a common European space. At the same time, the emphasis on cultural heritage at the local, regional, national, and EU levels challenged and linked the traditional national and contemporary transnational perspectives of cultural heritage. While the EYCH 2018 did not lead to a successful cooperation with the EHL as a network that explicitly promotes Europe's cultural heritage, other synergies with other initiatives and areas were developed during the $\mathrm{EYCH}$. The questions now are how European institutions will manage to make use of such synergies, and how to establish and integrate the ideas into cultural policies and cooperation.

An understanding of the economic and political uses of culture remains inherent in the current EU cultural policy. However, this risks the danger of reducing cultural processes to mere tools for managing and achieving social, economic, and political goals. The promotion of the EHL could help broaden the understanding of what culture and heritage mean to people, and thereby facilitate synergies between the urgent issues of sustainability and the economy on the one hand, and the social and cultural dimension of culture in people's lives on the other.

The EHL currently (in 2019) still forms a small and "exclusive club" of designated heritage sites, but it would be in the interest of the European Commission to raise awareness of the EHL action among a broader European public. Despite the clear political and educational objectives connected with its implementation, the EHL action nevertheless possesses the capacity to initiate a public debate on what European heritage is, by engaging with a broader spectrum of European citizens and actors beyond the cultural, academic, and political spheres. The strength of the EHL action consists in the network of designated heritage sites that promote different facets and a transnational understanding of cultural heritage. They should

69 Idem, The European Heritage... 


\section{GENERAL ARTICLES}

Viktorija L.A. Čeginskas

assist in maintaining and producing a sense of shared values and history in terms of a larger framework, one that incorporates and links manifold competing interpretations of local, regional, national, transnational, universal, and cosmopolitan viewpoints, including non-European or even migrant perspectives..$^{70}$ Thus, the EHL network can assist in demonstrating how national narratives of heritage and a national instrumentalization of heritage affect different aspects of everyday life. At the same time, highlighting a shared European heritage in the context of the EHL has the capacity to increase the understanding of Europe as a political and value-based community by helping to construct and support meaningful social connections and historical interconnections.

The explicit focus on a European heritage challenges national discourses and exclusionary narratives of heritage and belonging by communicating to a broader European public the understanding that cultural heritage is more than just conservational memory or national legacy, but also a source of new perspectives for creating and developing a common future. While the promotion of European heritage can produce an inclusionary understanding of heritage that serves the political objectives of European integration, at the same time it may strengthen a sense of belonging to Europe as a cultural and political community, based on a broad societal consensus on shared values and complementary interests across Europe. There is no contradiction between national responsibilities and the EU action, as heritage is always both local and European and has been forged over time and across borders and communities. There is no doubt that European citizens would benefit from concentrating on what unites them in today's times. European heritage offers a focus on what connects Europeans instead of what separates them, which may be a useful and topical way to reduce the prevalent sense of societal polarization across European societies and strengthen the position of the rule of law and respect for human rights in EU Member States.

\section{References}

Commission of the European Communities, European File 10/88: The European Community and Culture, May 1988, http://aei.pitt.edu/14726/1/EUR-FILE-10-88.pdf [accessed: 12.02.2019].

Convention Concerning the Protection of the World Cultural and Natural Heritage, 16 November 1972, 1037 UNTS 151.

Convention for the Safeguarding of the Intangible Cultural Heritage, 17 October 2003, 2368 UNTS 1.

Council of Europe Framework Convention on the Value of Cultural Heritage for Society, 27 October 2005, CETS 199.

70 Ibidem 
Council of the European Union, Resolution of the Council of 16 November 2007 on a European Agenda for Culture, OJ C 287, 29.11.2007, p. 1.

De Cesari C., European Heritage and Cultural Racism, paper presented at the conference "The Cultural Heritage of Europe @2018. Re-assessing a Concept and Re-defining Its Challenge", Institut national d'histoire de l'art (INHA), Paris, 4-5 June 2018.

De Clercq W., Reflections on Information and Communication Policy of the European Community. Report by the Group of Experts Chaired by Mr. Willy De Clerca, Member of the European Parliament, March 1993, http://aei.pitt.edu/29870/1/DE_CLERCQ_REPORT_INFO. COMM._POLICY.pdf [accessed: 12.02.2019].

Decision (EU) 2017/864 of the European Parliament and of the Council of 17 May 2017 on a European Year of Cultural Heritage (2018), OJ L 131, 20.05.2017, p. 1.

Decision No. 1194/2011/EU of the European Parliament and of the Council of 16 November 2011 establishing a European Union action for the European Heritage Label, OJ L 303, 22.11.2011, p. 1.

Delanty G., Entangled Memories: How to Study Europe's Cultural Heritage, "The European Legacy" 2017, Vol. 22(2).

Delanty G., The European Heritage. A Critical Re-interpretation, Routledge, London - New York 2017.

Delanty G., What Unites Europe and What Divides It? Solidarity and the European Heritage Reconsidered, "Asian Journal of German and European Studies" 2018, Vol. 3(3).

European Commission, A Renewed EU Tourism Policy: Towards a Stronger Partnership for European Tourism, 17 March 2006, COM(2006) 134 final.

European Commission, Commission Implementing Decision of 2.3.2012 on the Adoption of the 2012 Work Programme of a European Union Action for the European Heritage Label, 2 March 2012, C(2012) 1317 final.

European Commission, Commission Staff Working Document. Summary of the Impact Assessment. Accompanying Document to the Proposal for a Decision of the European Parliament and of the Council Establishing a European Union Action for the European Heritage Label, 9 March 2010, COM(2010) 76 final.

European Commission, Communication from the Commission to the European Parliament, the Council, the European Economic and Social Committee and the Committee of the Regions: Towards an Integrated Approach to Cultural Heritage for Europe, 22 July 2014, COM(2014) 477 final.

European Commission, Communication from the Commission to the European Parliament, the Council, the European Economic and Social Committee and the Committee of the Regions. A New European Agenda for Culture, 22 May 2018, COM(2018) 267 final.

European Commission, European Heritage Label. 2013 Panel Report, Brussels 2013.

European Commission, European Heritage Label. 2014 Panel Report, Brussels 2014.

European Commission, European Heritage Label. 2015 Panel Report, Brussels 2015.

European Commission, European Heritage Label. 2017 Panel Report, 5 December 2017.

European Commission, European Heritage Label. Guide for Candidate Sites, Brussels 2011.

European Commission, European Heritage Label. Panel Report on Monitoring, 19 December 2016. 


\section{GENERAL ARTICLES}

Viktorija L.A. Čeginskas

European Parliament legislative resolution of 16 November 2011 on the Council position at first reading with a view to the adoption of a decision of the European Parliament and of the Council establishing a European Union action for the European Heritage Label, 16 November 2011, P7_TA(2011) 0502.

Harrison R., Heritage. Critical Approaches, Routledge, New York 2013.

Kaiser S., The European Heritage Label. A Critical Review of a New EU Policy [Ph.D. diss.], University of Illinois 2014.

Lähdesmäki T. et al. (eds.), Dissonant Heritages and Memories in Contemporary Europe, Palgrave Macmillan, forthcoming.

Lähdesmäki T., Founding Myths of European Union: Europe and the Workings of Power in the European Union Heritage and History Initiatives, "European Journal of Cultural Studies" 2018, DOI: $10.1177 / 1367549418755921$.

Lähdesmäki T., Politics of Affect in the EU Heritage Policy Discourse: An Analysis of Promotional Videos of Sites Awarded with the European Heritage Label, "International Journal of Heritage Studies" 2017, Vol. 23(1).

Lähdesmäki T., Politics of Tangibility, Intangibility, and Place in the Making of European Cultural Heritage in EU Heritage Policy, "International Journal of Heritage Studies" 2016, Vol. 22(10).

Lähdesmäki T., Rhetoric of Unity and Cultural Diversity in the Making of European Cultural Identity, "International Journal of Cultural Policy" 2012, Vol. 18(1).

Lähdesmäki T., The EU's Explicit and Implicit Heritage Politics, "European Societies" 2014, Vol. 16(3).

Lähdesmäki T., Mäkinen K., Dynamics of Scale in the Making of a European Cultural Heritage in EU Heritage Policy, in: T. Lähdesmäki, S. Thomas, Y. Zhu (eds.), Politics of Scale. New Direction in Critical Heritage Studies, Berghahn Books, New York 2019.

Niklasson E., The Janus-face of European Heritage: Revisiting the Rhetoric of Europe-making in EU Cultural Politics, "Journal of Social Anthropology" 2017, Vol. 2.

Niklasson E., Hølleland H., The Scandinavian Far-right and the New Politicization of Heritage, "Journal of Social Anthropology" 2018, Vol. 18(2).

Rendall A., Euro MPs Back Creation of 'European Heritage Label', BBC, 16 November 2011, https://www.bbc.com/news/uk-politics-15755426 [accessed: 10.02.2019].

Riksantikvarieämbetet, Rapport från Riksantikvarieämbetet: Europeiskt kulturarvsmärke, Riksantikvarieämbetet, Stockholm 2016.

Sassatelli M., Becoming Europeans. Cultural Identity and Cultural Policies, Palgrave Macmillan, Basingstoke - New York 2009.

Schorch P., Waterton E., Watson S., Museum Canopies and Affective Cosmopolitanism. Cultivating Cross-cultural Landscapes for Ethical Embodied Responses, in: D.P. Tolia-Kelly, E. Waterton, S. Watson (eds.), Heritage, Affect and Emotion. Politics, Practices and Infrastructures, Routledge, London - New York 2017.

Shore C., Building Europe. The Cultural Politics of European Integration, Routledge, London New York 2000.

Treaty establishing a Constitution for Europe, signed on 29 October 2004 (not in force), OJ C 310, 16.12.2004. 
Treaty on the Functioning of the European Union (consolidated version), OJ C 326, 26.10.2012, p. 47.

Trenz H.-J., The Saga of Europeanisation. On the Narrative Construction of a European Society (Arena Working Paper 7/2014), July 2014, https://www.sv.uio.no/arena/english/research/publications/arena-working-papers/2014/wp7-14.pdf [accessed: 5.11.2018].

Table 1. List of EHL heritage sites and year of designation

\begin{tabular}{|c|c|}
\hline $\begin{array}{l}\text { Krapina Neanderthal Site, } \\
\text { Croatia (2015) }\end{array}$ & $\begin{array}{l}\text { Dohány Street Synagogue Complex, } \\
\text { Budapest, Hungary (2017) }\end{array}$ \\
\hline $\begin{array}{l}\text { The Heart of Ancient Athens, } \\
\text { Greece (2014) }\end{array}$ & $\begin{array}{l}\text { Mundaneum, Mons, } \\
\text { Belgium (2015) }\end{array}$ \\
\hline $\begin{array}{l}\text { Archaeological Park Carnuntum, } \\
\text { Austria (2013) }\end{array}$ & $\begin{array}{l}\text { Peace Palace, The Hague, } \\
\text { The Netherlands (2013) }\end{array}$ \\
\hline $\begin{array}{l}\text { Abbey of Cluny, } \\
\text { France (2014) }\end{array}$ & $\begin{array}{l}\text { Javorca Church and its Cultural } \\
\text { Landscape, Tolmin, Slovenia (2017) }\end{array}$ \\
\hline $\begin{array}{l}\text { Olomouc Premyslid Castle } \\
\text { and Archdiocesan Museum, } \\
\text { Czech Republic (2015) }\end{array}$ & $\begin{array}{l}\text { Residencia de Estudiantes, Madrid, } \\
\text { Spain (2014) }\end{array}$ \\
\hline $\begin{array}{l}\text { Archive of the Crown of Aragon, } \\
\text { Barcelona, Spain (2014) }\end{array}$ & $\begin{array}{l}\text { World War I Eastern Front Cemetery } \\
\text { No. 123, Łużna-Pustki, Poland (2015) }\end{array}$ \\
\hline $\begin{array}{l}\text { Leipzig's Musical Heritage Sites, } \\
\text { Germany (2017) }\end{array}$ & $\begin{array}{l}\text { Kaunas of 1919-1940, } \\
\text { Lithuania (2014) }\end{array}$ \\
\hline $\begin{array}{l}\text { Great Guild Hall, Tallinn, } \\
\text { Estonia (2013) }\end{array}$ & $\begin{array}{l}\text { Camp Westerbork, } \\
\text { The Netherlands (2013) }\end{array}$ \\
\hline $\begin{array}{l}\text { Sagres Promontory, } \\
\text { Portugal (2015) }\end{array}$ & $\begin{array}{l}\text { Former Natzweiler concentration camp } \\
\text { and its satellite camps, Alsace-Moselle, } \\
\text { Haut Rhin / France - } \\
\text { and Baden-Württemberg, Hessen, } \\
\text { Rhineland-Palatinate / Germany (2017) }\end{array}$ \\
\hline $\begin{array}{l}\text { General Library of the University } \\
\text { of Coimbra, Portugal (2014) }\end{array}$ & $\begin{array}{l}\text { Franja Partisan Hospital, } \\
\text { Slovenia (2014) }\end{array}$ \\
\hline $\begin{array}{l}\text { The Imperial Palace, Vienna, } \\
\text { Austria (2015) }\end{array}$ & $\begin{array}{l}\text { Sighet Memorial, Sighet, } \\
\text { Romania (2017) }\end{array}$ \\
\hline Union of Lublin, Poland (2014) & Bois du Cazier, Marcinelle, Belgium (2017) \\
\hline $\begin{array}{l}\text { Münster and Osnabrück - Sites } \\
\text { of the Peace of Westphalia, } \\
\text { Germany (2014) }\end{array}$ & $\begin{array}{l}\text { European District of Strasbourg, } \\
\text { France (2015) }\end{array}$ \\
\hline
\end{tabular}




\section{GENERAL ARTICLES}

Viktorija L.A. Čeginskas

\begin{tabular}{|l|l|}
\hline $\begin{array}{l}\text { The May 3, 1791 Constitution, Warsaw, } \\
\text { Poland (2014) }\end{array}$ & $\begin{array}{l}\text { Museo Casa Alcide De Gaspari, Pieve, } \\
\text { Tesino, Italy (2014) }\end{array}$ \\
\hline $\begin{array}{l}\text { The Historic Ensemble of the University } \\
\text { of Tartu, Estonia (2015) }\end{array}$ & $\begin{array}{l}\text { Robert Schuman's House, Scy-Chazelles, } \\
\text { France (2014) }\end{array}$ \\
\hline $\begin{array}{l}\text { Hambach Castle, } \\
\text { Germany (2014) }\end{array}$ & $\begin{array}{l}\text { The Historical Gdańsk Shipyard, } \\
\text { Poland (2014) }\end{array}$ \\
\hline $\begin{array}{l}\text { Fort Cadine, Trento, } \\
\text { Italy (2017) }\end{array}$ & $\begin{array}{l}\text { Pan-European Picnic Memorial Park, } \\
\text { Sopron, Hungary (2014) }\end{array}$ \\
\hline $\begin{array}{l}\text { Charter of Law of Abolition of the Death } \\
\text { Penalty, Lisbon, Portugal (2014) }\end{array}$ & $\begin{array}{l}\text { Village of Schengen, Schengen, } \\
\text { Luxembourg (2017) }\end{array}$ \\
\hline $\begin{array}{l}\text { Ferenc Liszt Academy of Music, Budapest, } \\
\text { Hungary (2015) }\end{array}$ & $\begin{array}{l}\text { Maastricht Treaty, Maastricht, } \\
\text { The Netherlands (2017) }\end{array}$ \\
\hline
\end{tabular}

Source: Own elaboration. 